\title{
HEALTH DIFFERENCES BETWEEN POPULATIONS OF THE UNITED STATES OF AMERICA AND THE EUROPEAN UNION
}

\author{
Emil Ginter ${ }^{1}$, Vladimir Simko² \\ 'Institute of Preventive and Clinical Medicine, Bratislava, Slovakia \\ ${ }^{2}$ State University of New York, Downstate Medical Center at Brooklyn, NY, USA
}

\begin{abstract}
SUMMARY
This review documents health care outcome in relation to health expenditure in the US and in the European Union (EU) and it attempts to interpret the root cause of observed differences. In comparison with the US where the per capita expenditure for health care is close to 8,000 international dollars, health expenditure in the Western European Countries (WEC) (France, Germany, Britain, Italy) is approximately only half of that in the US. In the Central and Eastern European Countries (CEEC) it is 20 per cent or less of the US health care budget. Infant mortality in the US is much higher than in the WEC and some CEEC (Czech Republic, Poland, Hungary and Slovakia) countries are even better off in infant mortality than the US. Concerning the male life expectancy, Caucasian Americans rank the lowest of the WEC, representing a statistical boundary between the WEC and the CEEC. Like the American caucasian males, the American Caucasian females rank at the lowest range of the WEC. Afro-American females have values substantially worse, almost along the lowest ranking CEEC. European societies have been established for centuries, cherishing strong social values. The US is a much younger rapidly developing multi-ethnic community that derived its progress from adhering to traditions and principles of free choice. Witness to the rate at which the US society can resolve difficult social problems is the enormous progress in eliminating racial discrimination during the past fifty years.
\end{abstract}

Key words: European Union, USA, health expenditure, infant mortality, premature mortality

Address for correspondence: E. Ginter, Račianska 17, 83102 Bratislava, Slovakia. E-mail: ginter.emil@mail.t-com.sk

\section{INTRODUCTION}

Life expectancy (LE) is associated with the living standard, economy of individual countries. While the LE (males+females) of countries that are economically inferior is very low (30 to 40 years in Swaziland, Angola, Zambia, Sierra Leone) and the infant mortality is very high, countries with better economy have a LE of 60 to 70 years (India, Russia, Pakistan, Bangladesh, Bolivia, Ghana). How does this compare with the LE in the United States of America (US) and in the European Union (EU)? LE in WEC is 80 to 82 , but in the US it is only 79 years. Surprisingly, health investment of the US society are two- to three-fold higher than in the EU countries that proud themselves of superior health accomplishment.

\section{METHODS}

Statistical data originate from the World Health Organization (WHO) and the US National Center for Health Statistics (1-5).

Definitions: Life expectancy (LE): the average number of years a person may expect to live, based on age-specific mortality data; Life expectancy at birth is also a measure of overall quality of life in a country and summarizes the mortality at all ages. Healthy life expectancy (HALE): the number of years a person may expect to live in good health, based on a group of measures. Healthy life expectancies are calculated by subtracting the years in poorer health from a person's life expectancy, and thus combine information on mortality and ill-health. Infant mortality is defined as the number of infant deaths (one year of age or younger) per 1000 live births. Health expenditure is expressed in purchasing power parity (PPP) which is adjusted to the relative domestic purchasing power of the national currency as compared to the US dollar, rather than using the official exchange rate.

\section{RESULTS}

The EU was set up in the aftermath of World War Two by an initial association of non-communist countries with marketoriented economy. Country partnership gradually increased and after the fall of the communist system, the most recent expansion of the EU in 2007 resulted in a 27 country membership. WEC were never exposed to the totalitarian political economic system as opposed to the CEEC that joined the EU after 1989. Newly admitted post-communist countries joined with a lower economic level, lower living standard and markedly lower health care budgets (Fig. 1). In comparison with the US where the per capita expenditure for health care is close to 8,000 international dollars, health expenditure in the WEC (France, Germany, Britain, 


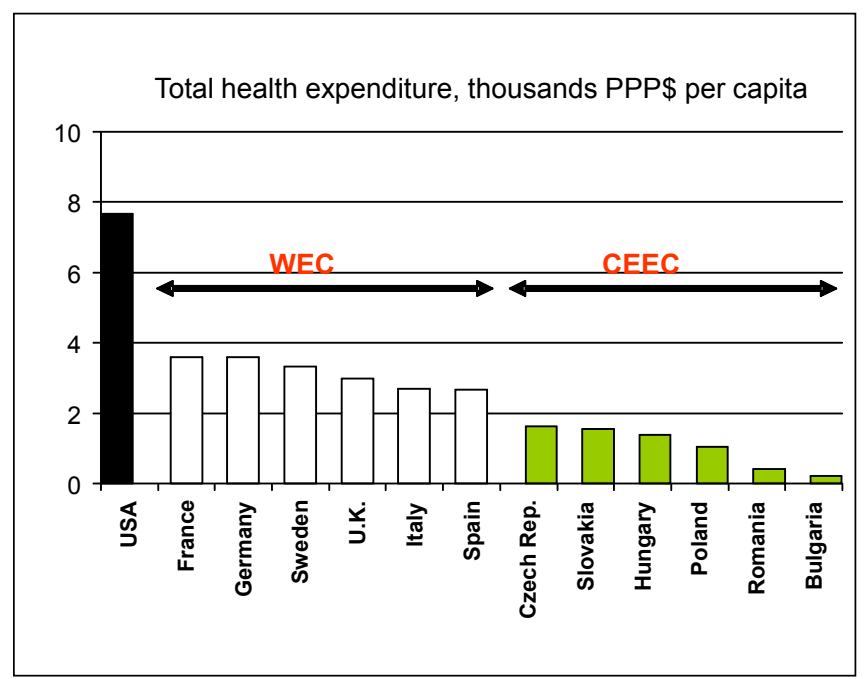

Fig. 1. Great difference in health expenditure in USA and European Union.

Italy) is approximately only half of that in the US. In the CEEC it is 20 per cent or less of the US health care budget.

The infant mortality rate correlates very strongly with and is among the best predictors of the quality of health care. Remarkably, this indicator is disproportionately high in the US. Infant mortality in the US is much higher than in the WEC and even in some CEEC - (Fig. 2). An important factor in the US infant mortality is the health of Afro-American babies. During 2003-5 the infant mortality in the US was highest for Afro-Americans $(13,3)$, followed by Native Americans $(8,4)$, Caucasians $(5,7)$ and Asians (4,8). Afro-American infants were about 3 times as likely as Asian infants to die during the first year of life. The drop in the US infant mortality is fairly slow. In the 1996 this index was 7.3 and in 2005 it was 6.9. The infant mortality in the US continues to rank at about 33 among the world countries, being higher than that in Cuba and South Korea. On the other side, Czech Republic belongs to the countries with the best rate of infant mortality in

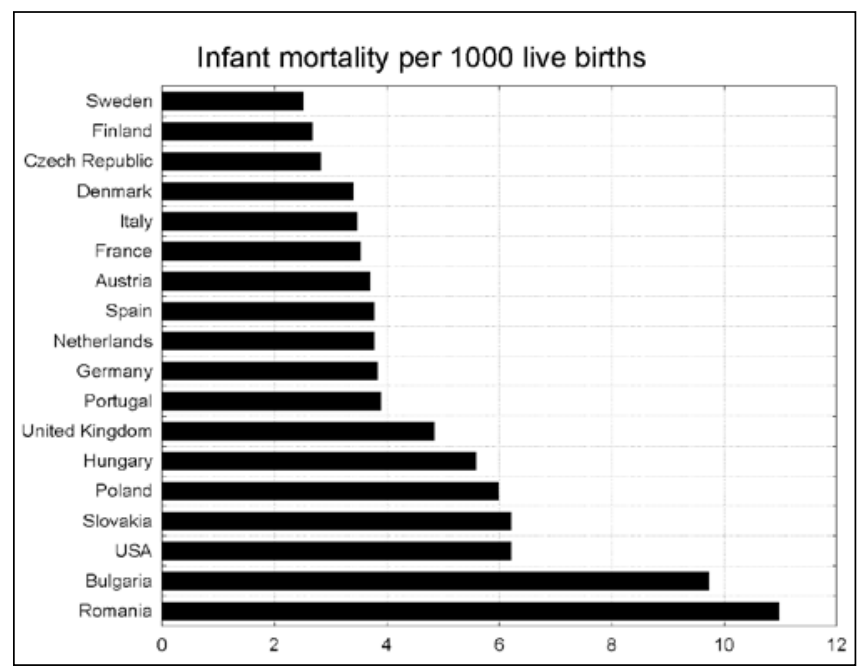

Fig. 2. Different trends in male life expectancy in USA and non-communist European Union (WEC). the world for a long time. In this country a high quality of infant health care (availability of prenatal and neonatalogical care) was provided even during communist era.

Table 1 compares the male LE and HALE in the USA and in the EU. Caucasian Americans rank the lowest of WEC, representing a statistical boundary between the WEC and the CEEC. Afro-American males are even worse off: their values rank among the CEEC. Table 2 illustrates the female LE and HALE in the US and in the EU. Like the American Caucasian males, the American Caucasian females rank at the lowest range of the WEC. Afro-American females have values substantially worse, almost along the lowest ranking. Fig. 3 shows the trend in male LE in the US and in the WEC. While in the 1980 the difference in LE of US versus EU was less than one year, more recently this difference is about two years, in disfavour of the US. Fig. 4 documents the trend in the LE that is for US women even more unfavourable than for US men, in comparison with the WEC. In the 1984 American women had similar LE as the EU but in 2007 the LE in WEC was better by two years than in the US. Even in the CEEC, in the Czech Republic the LE of women improved, almost reaching the US level.

When we consider regional differences, it is conceivable that like in the US there are also marked differences in the LE (men+women) in the EU. Best LE in the US is in Hawaii (80 years), in EU it is Switzerland, Iceland, Italy and Spain (82 years). Lowest LE in the US is in Washington, D.C. (72 years), in the EU it is Latvia and Lithuania (72 years). An important factor in the US is the proportion of minority population.

Table 1. Male Life Expectancy at birth (LE) and Healthy Life Expectancy (HALE) in European Union and USA. Last available data (2006-2008)

\begin{tabular}{|l|c|c|}
\hline Country & Life expectancy & $\begin{array}{c}\text { Healthy life } \\
\text { expectancy }\end{array}$ \\
\hline Iceland & 80.1 & 73.0 \\
\hline Sweden & 79.3 & 72.3 \\
\hline Italy & 78.8 & 72.5 \\
\hline Austria & 77.9 & 70.5 \\
\hline Greece & 77.8 & 70.7 \\
\hline France & 77.8 & 77.1 \\
\hline U.K. & 77.7 & 70.8 \\
\hline Germany & 77.2 & 71.1 \\
\hline Spain & 78.4 & 71.5 \\
\hline Finland & 76.6 & 69.6 \\
\hline USA-Caucasian & 76.0 & 68.0 \\
\hline Czech Republic & 74.2 & 67.8 \\
\hline Poland & 71.3 & 64.1 \\
\hline Slovakia & 70.3 & 64.2 \\
\hline Hungary & 70.0 & 62.3 \\
\hline Romania & 69.9 & 62.8 \\
\hline USA-Afro-American & 69,5 & 61,0 \\
\hline Bulgaria & 69,8 & 63,2 \\
\hline Estonia & 68,7 & 61,3 \\
\hline
\end{tabular}


Table 2. Female Life Expectancy at birth (LE) and Healthy Life Expectancy (HALE) in European Union and USA. Last available data (2006-2008)

\begin{tabular}{|l|c|c|}
\hline Country & Life expectancy & $\begin{array}{c}\text { Healthy life } \\
\text { expectancy }\end{array}$ \\
\hline France & 85.0 & 75.7 \\
\hline Italy & 84.4 & 76.0 \\
\hline Spain & 84.7 & 76.1 \\
\hline Sweden & 83.4 & 74.9 \\
\hline Austria & 83.4 & 74.2 \\
\hline Finland & 83.4 & 74.7 \\
\hline Netherlands & 82.6 & 74.0 \\
\hline Germany & 82.4 & 74.6 \\
\hline Greece & 82.5 & 74.2 \\
\hline U.K. & 81.9 & 73.4 \\
\hline Portugal & 81.6 & 73.1 \\
\hline USA-Caucasian & 81.0 & 72.0 \\
\hline Czech Republic & 80.6 & 72.2 \\
\hline Poland & 80.1 & 70.2 \\
\hline Slovakia & 78.2 & 70.2 \\
\hline Estonia & 79.6 & 70.6 \\
\hline Hungary & 78.3 & 69.3 \\
\hline Romania & 77.5 & 67.7 \\
\hline USA-Afro-American & 76.9 & 68.0 \\
\hline Bulgaria & 77.1 & 68.7 \\
\hline
\end{tabular}

\section{DISCUSSION}

Despite the claim by many in the US health policy community that international comparison is not useful because of the uniqueness of the United States it is hard to ignore that in 2006, the USA was number 1 in terms of health care spending per capita but internationally it ranked 39th for infant mortality, 43rd for adult female mortality, 42nd for adult male mortality, and 36th for life expectancy. A baby born in the United States in 2009 will live in average 78 years, ranking America as the 50th worldwide. That is down from 11th position two decades earlier. These facts have fueled a question now being discussed in academic circles, as well as by government and the public: Why does the US spend so much to get so little? (6-8).

One potential factor responsible for health differences between the US and the EU is obesity (Fig. 5). Caucasian American males rank among the heaviest, together with Czechs, Brittons and Germans. Afro-Americans are even more afflicted with obesity. In Afro-American males obesity is three times more prevalent than among Italians. The 40 per cent prevalence of obesity among US Afro-American females tops the female obesity. Smoking does not seem to explain health differences between the US and the EU. American men and women smoke less than the Europeans. Smoking rates among Afro-American adults historically have been higher than among the general US population; however, in recent years smoking rates have been similar. The European

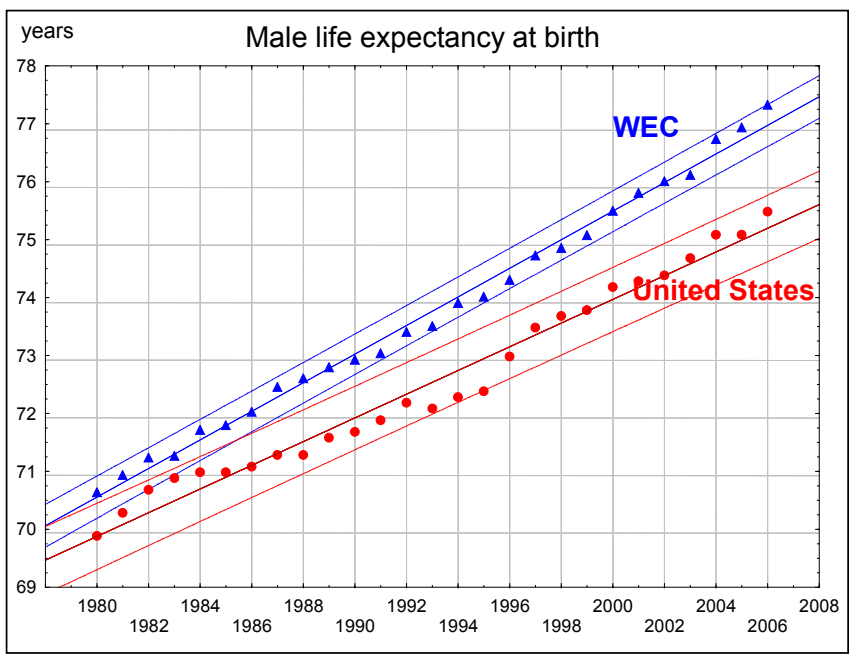

Fig. 3. Different trends in female life expectancy in USA, noncommunist European Union (WEC) and in the Czech Republic.

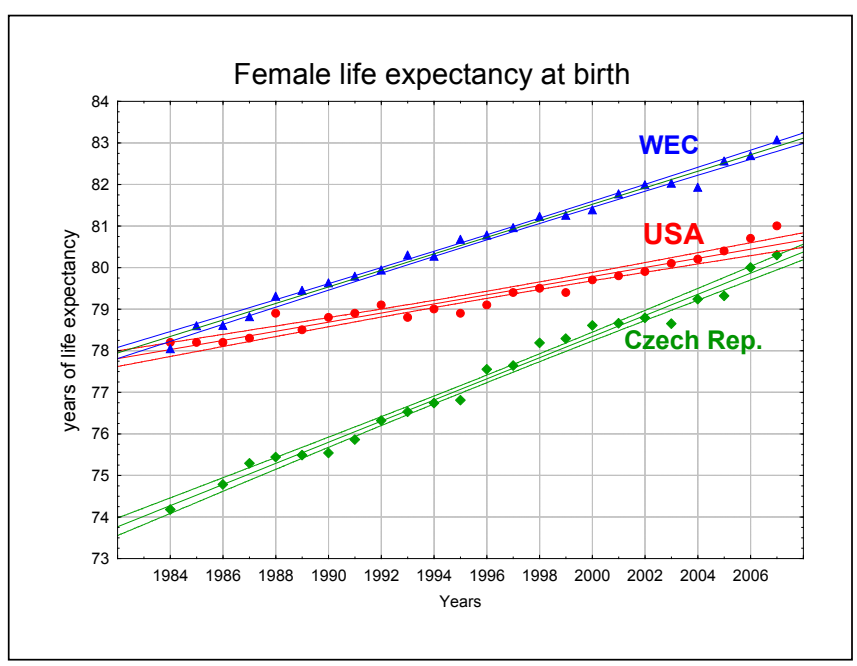

Fig. 4. Very high infant mortality rate in USA.

Adult obesity prevalence (\%) in the European Union and USA

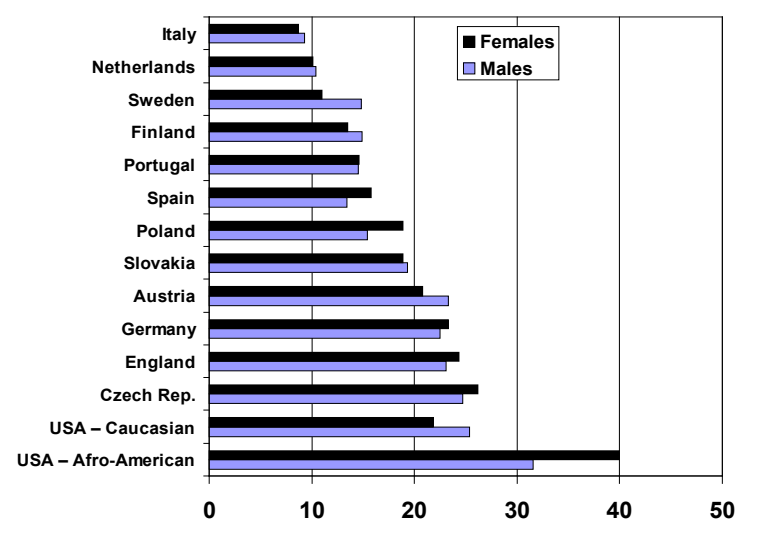

Fig. 5. Very high obesity prevalence in Afro-American females. 
Union has been active in tobacco control policy since 1985 (9). It is obvious that the root causes of health differences between the US and the EU are much more complex, based not only on American economic and historic traditions but also on political forces integrating with social, ethnic and private enterprise mechanisms.

Health care consumed a record 17.3 per cent of all spending in the US economy in 2009. Yet, about 17.5 per cent of the US population is uninsured. Thirteen million or 29 per cent of young adults ages 19 to 29 were one of the largest segments of the US population without insurance in 2007 . The proportion of uninsured has increased also because of lost employment and decreased family wealth in the present economic crisis (10). Growth in health care spending may be beneficiary. But the US health care system is loaded with inefficiency. Almost all stake holders agree that a change in health care is essential to put an end to the status of the US as the only developed country that places a large segment of its citizens at risk for medical bankruptcy. Demographic trends in the US indicate that by 2050 the members of present racial and ethnic minorities will be in the majority. Minority groups account for half of the uninsured population and they have higher rates of disease and more limited access to care than their Caucasian counterparts. 20,000 US people each year die for want of health insurance (11). For example, uninsured trauma patients had significantly higher mortality especially when they were AfroAmerican or Hispanic (12). Presently, most health plans do not analyze the quality of care delivered according to patient's race or ethnic group. If millions of minority patients are brought into the health care system, it is important to ensure that health plans have resources to meet their needs. High expenditure does not necessarily mean better health care outcome. While health care reform must not endanger traditional American sense for liberty, e.g. freedom to choose a physician, there is even a broader range of values the health care has to embody. These include also justice and fairness, responsibility, medical progress, privacy and physician integrity. If everyone is to receive care when it is needed, fairness and responsibility require that everyone participate in financing it. A policy of universal participation eliminates adverse selection when participants join insurance only when they get sick. In Europe there are growing numbers of non-governmental organizations concerned with public health (13).

\section{CONCLUSION}

Differences in health care expenditure and health outcome between the populations of the United States and the European Union provide important lesson for health managers on both sides of the Atlantic. Important health indices, life expectancy and infant mortality do not reflect the very large investment in US health care, compared to the EU. European societies have been established for centuries, cherishing strong social values. The United States is a much younger rapidly developing multi-ethnic community that derived its progress from adhering to traditions and principles of free choice and its wealth from benefits of the market economy. Witness to the rate at which the US society can resolve difficult social problems is the enormous progress in eliminating racial discrimination during the past fifty years. There are some crucial factors, especially social and income inequalities which are going beyond the ethnicity issues (14). These factors create the background for social determinants of health (not only for Afro-American people in USA and for Roma people in Europe).

\section{REFERENCES}

1. European Health for All Database (HFA-DB) [Internet]. Copenhagen: WHO Regional Office for Europe [cited $2010 \mathrm{Jul} 15]$. Available from: http://www.euro.who.int/hfadb.

2. Mortality indicators by 67 causes of death, age and sex (HFA-MDB) [Internet]. Copenhagen: WHO Regional Office for Europe [cited 2010 Jul 15]. Available from: http://www.euro.who.int/hfadb.

3. WHO Statistical information system (WHOSIS) [Internet]. Geneva: World Health Organization; 2010 [cited 2010 Jul 15]. Available from: http://www.euro.who.int/hfadb.

4. World Health Organization. World health statistics 2009. Geneva: WHO; 2009.

5. Health, United States, 2008. Hyattswille (MD): National Center for Health Statistics; 2009.

6. Murray CJ, Frenk J. Ranking 37th - measuring the performance of the U.S. health care system. N Engl J Med. 2010 Jan 14;362(2):98-9.

7. Weinstein MC, Skinner JA. Comparative effectiveness and health care spending-implications for reform. N Engl J Med. 2010 Feb 4;362(5):4605

8. Wilper AP, Woolhandler S, Lasser KE, McCormick D, Bor DH, Himmelstein DU. Health insurance and mortality in US adults. Am J Public Health. 2009 Dec;99(12):2289-95.

9. Godfrey F. An overview of European Union tobacco control legislation. Cent Eur J Public Health. 2000 May;8(2):128-31.

10. Chernew ME, Sabik L, Chandra A, Newhouse JP. Ensuring the fiscal sustainability of health care reform. N Engl J Med. 2010 Jan 7;362(1):1-3

11. Murray TH. American values and health care reform. N Engl J Med. 2010 Jan 28;362(4):285-7.

12. Salim A, Ottochian M, duBose J, Inaba K, Teixeira P, Chan LS, et al. Does insurance status matter at a public, level I trauma center? J Trauma. 2010 Jan;68(1):211-6.

13. Gulis G, Garrido-Herrero L, Katreniakova Z, Harvey G, McCarthy M; Slovak Public Health Association. Public health research priorities in Europe seen by non-governmental organizations. Cent Eur J Public Health. 2008 Dec;16(4):209-12.

14. Marmot M, Wilkinson R, editors. Social determinants of health. 2nd ed. Oxford: Oxford University Press; 2006.

Received February 22, 2010 Accepted in revised August 25, 2010 